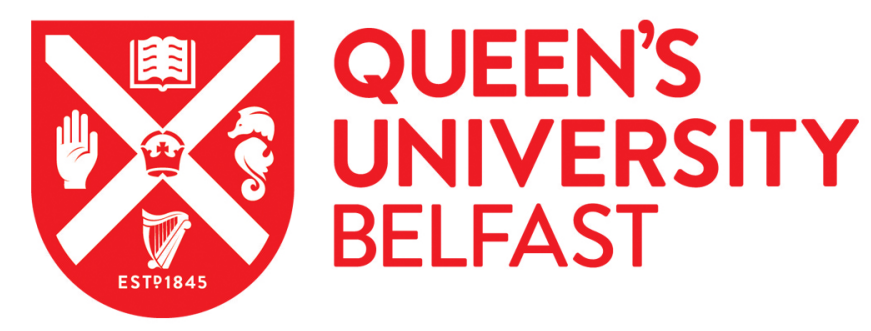

\title{
Intermarriage in fifteenth-century Ireland: the English and Irish in the 'four obedient shires'
}

Booker, S. (2013). Intermarriage in fifteenth-century Ireland: the English and Irish in the 'four obedient shires'. Proceedings of the Royal Irish Academy: Section C. Archaeology, Celtic Studies, History, Linguistics, Literature, 113, 219-250. https://doi.org/10.3318/PRIAC.2013.113.02

Published in:

Proceedings of the Royal Irish Academy: Section C, Archaeology, Celtic Studies, History, Linguistics, Literature

Document Version:

Peer reviewed version

Queen's University Belfast - Research Portal:

Link to publication record in Queen's University Belfast Research Portal

Publisher rights

( 2013 Royal Irish Academy. This work is made available online in accordance with the publisher's policies. Please refer to any applicable terms of use of the publisher.

\section{General rights}

Copyright for the publications made accessible via the Queen's University Belfast Research Portal is retained by the author(s) and / or other copyright owners and it is a condition of accessing these publications that users recognise and abide by the legal requirements associated with these rights.

Take down policy

The Research Portal is Queen's institutional repository that provides access to Queen's research output. Every effort has been made to ensure that content in the Research Portal does not infringe any person's rights, or applicable UK laws. If you discover content in the Research Portal that you believe breaches copyright or violates any law, please contact openaccess@qub.ac.uk. 


\title{
Intermarriage in fifteenth century Ireland: the English and Irish in the 'four obedient shires'
}

\author{
SPARKY BOOKER* \\ Department of History and Humanities, Trinity College Dublin
}

[Accepted 1 March 2012.]

\begin{abstract}
Many attempts have been made to understand and explain the complicated relationship between the English of Ireland and the Irish in the later middle ages. This paper explores the interaction between these two groups through the curiously understudied phenomenon of intermarriage, and centres on the 'four obedient counties' of Dublin, Meath, Louth, and Kildare in the fifteenth century. These counties, which later comprised the Pale, were home to an English community that helped to produce much of the anti-Irish rhetoric found in record sources of the fifteenth century, including frequent enactments that prohibited marriage between the English and the Irish. And yet, English men and women from this region chose to marry Irish people, and they did so in much greater numbers than the current historiography acknowledges. The prevalence of intermarriage in the four counties indicates that the English and Irish interacted far more peaceably and amicably than the often belligerent attitudes displayed toward the Irish in records from the colony would indicate, and that the attempts made by the Irish parliament to distance the English of Ireland from their Irish neighbours were largely unsuccessful.
\end{abstract}

\section{Introduction}

The nature of the relationship between the English of Ireland and the Irish is perhaps the most disputed question in the historiography of late medieval Ireland. Many of the surviving documents from this period, particularly those generated by the Dublin-centred English administration of Ireland, display an anti-Irish mindset and consistently use the term 'Irish enemy' to describe the native Irish. The sources most widely used by historians give the impression of division and seemingly unrelenting hostility between the English and the Irish in the fifteenth century. Thus the equally prevalent accommodation and cooperation between the two peoples can easily be underestimated. Nowhere is this cooperation more evident, or more symbolically realised, than in the institution of marriage. The English invasion of Ireland in the twelfth century famously resulted in one such union- that of Richard fitz Gilbert de Clare, or Strongbow, the English leader of the invasion, and Aífe, daughter of his Irish ally, Diarmait Mac Murchadha. ${ }^{1}$ In time, and throughout the medieval period, the presence of the English in Ireland led to many more marriages which spanned the ethnic division of English and Irish.

\footnotetext{
*Author's e-mail: abooker@tcd.ie doi: 10.3318/PRIAC.2012.113.XXXX

${ }^{1}$ There is some disagreement about what name is most appropriate for the settlers in Ireland; Strongbow and his allies have given the appellation 'Cambrio-Norman' and the settlers, once established in Ireland, have often been called 'Anglo-Irish'. While these terms are useful in that they reflect the complexity of the identity of the settlers, I have chosen to use 'English' and 'English of Ireland' to describe these groups, as these are the terms they themselves most often favoured: John Gillingham, 'Normanizing the English invaders of Ireland' in H. Pryce and J.A. Watts (eds), Power and identity in the middle ages: essays in memory of Rees Davies (Oxford, 2007), 85-97; Steven Ellis “"More Irish than the Irish themselves”: the “Anglo-Irish” in Tudor Ireland', History Ireland, 7 (1) (1999), 22-6; K.W. Nicholls, 'Worlds apart? The Ellis two-nation theory on late medieval Ireland', History Ireland, 7 (2) (1999), 22-6.
} 
The so-called 'four obedient shires' ${ }^{2}$ of Meath, Kildare, Louth and Dublin are a fruitful area for a study of marriage between the English of Ireland and the Irish, as these counties comprised the region of the colony most firmly under English control in the fifteenth century. ${ }^{3}$ Much of the anti-Irish rhetoric that survives in sources from the period, particularly in the legislation of the Irish parliament, originated in these counties and was generated by the self-aware community of the region, later called 'Palesmen', who touted themselves as the most 'English' of the settlers in Ireland. ${ }^{4}$ It is among these individuals that such marriages are most interesting and, it could be argued, surprising. One might question why these marriages are notable, as, by the fifteenth century, the English of Ireland had lived in close proximity to the Irish for hundreds of years and naturally assimilated, at least partially, with their neighbours. Robin Frame has given a salutary warning about this, as he terms it, 'naive' assumption that time and proximity breed assimilation, and it is certainly worth bearing in mind that this is not necessarily always the case. ${ }^{5}$ One could point to the fact that the anti-Irish rhetoric of the settler community increased, rather than waned, in the later middle ages. Nevertheless, it is a rare colonial community that is able to hold itself entirely remote from its host culture, and the English of Ireland did, either from choice or necessity, adopt more and more Irish customs as the late middle ages progressed. ${ }^{6}$ In many cases, this adoption of Irish customs went hand in hand with intermarriage

Intermarriage among the settler elite of the four counties is well documented. ${ }^{7}$ Members of the powerful Fitzgerald family of Kildare, for example, frequently intermarried with the Irish and one

\footnotetext{
${ }^{2}$ The phrase 'four obedient shires' is first recorded in 1488, but the term 'four counties' appears in 1450 . The four counties were grouped together, as detailed in note 3, from the start of the fifteenth century: Charles McNeill (ed.), Calendar of Archbishop Alen's register (Dublin, 1950), 250; Henry F. Berry (ed.), Statute rolls of the parliament of Ireland: Henry VI (London, 1910), 225.

${ }^{3}$ Although this area was not given its own name, the 'Pale', until Poynings' parliament in 1494-5, it was treated as a distinct region, and the most 'English' part of the colony, throughout much of the fifteenth century. These four counties appear grouped together in documents of the Irish chancery in 1402-3 and 1414-15, although sometimes, particularly in the first decades of the fifteenth century, County Carlow appears alongside them: Edward Tresham (ed.), Rotulorum patentium et clausorum cancellarice Hibernice calendarium(Calendar of the patent and close rolls of the chancery of Ireland) (Dublin, 1828), 136, no 206, 165, no 228, 209, nos 171, 187, 188, 190. Provision was made to defend these four counties with tower houses in 1429-30, but by 1435 the Irish council complained that 'the nether parts of the counties of Dublin, Meath, Louth, and Kildare, that join together, out of the subjection of the said enemies and rebels scarcely thirty miles in length and twenty miles in breadth, thereas a man may surely ride or go in the said counties to answer the king's writs and to his commandments': William Betham, Dignities, feudal and parliamentary and the constitutional legislature of the United Kingdom (London, 1830), 361; H.G. Richardson and G.O. Sayles, The Irish parliament in the Middle Ages (Philadelphia, 1952), 180, note 40. For one of the most recent discussions of both documentary and archaeological evidence for the emergence of this area, see Margaret Murphy and Michael Potterton, The Dublin region in the Middle Ages (Dublin, 2010), 264-683.

${ }^{4}$ The work of Steven Ellis, particularly, has highlighted the self-consciously English aspect of settler identity: 'Nationalist historiography and the English and Gaelic worlds in the late middle ages', Irish Historical Studies (hereafter IHS) 25 (97) (1986-7), 1-18. Additionally, a great deal of work on this community and its identity has been done by early modernists: Brendan Bradshaw, The Irish constitutional revolution of the sixteenth century (Cambridge 1979); Nicholas Canny, The formation of the Old English elite in Ireland (Dublin, 1975); Ciaran Brady, The chief governors: the rise and fall of reform government in Tudor Ireland (Oxford, 1994).

${ }^{5}$ Robin Frame, “'Les Engleys nées en Irlande": the English political identity in medieval Ireland', Transactions of the Royal Historical Society 6 (3) (1993), 83-103: 89.

${ }^{6}$ The Irish customs adopted ranged from clothing and hairstyles to forms of taxation and social interaction. For those families who took on these customs most, see K.W. Nicholls, Gaelic and gaelicized Ireland in the Middle Ages (Dublin, 2003). Assimilation and intermarriage were evident in other English colonies in this period, as in English-held areas of France in the early fifteenth century and in Wales, by the fourteenth century: Robert Massey, 'Lancastrian Rouen: military service and property holding 1419-49' in David Bates and Anne Curry (eds), England and Normandy in the Middle Ages (London, 1994), 269-86; C.T. Allmand, Lancastrian Normandy 1415-1450 (Oxford, 1983), 102; R.R. Davies, The age of conquest: Wales, 1063-1415 (Oxford, 2000), 421-2.

${ }^{7}$ Settler families from elsewhere in the colony, like the Burkes of Connacht and the Butlers of Munster, also routinely intermarried with the Irish in this period: Lambert McKenna (ed.), Aithgioghluim Dána (2 vols, Dublin, 1939), vol. 1, 143-6, 152, 158, 163, 187; Henry F. Berry and James Morrissey, Statute rolls of the
} 
of the most famous inter-ethnic marriages of the fifteenth century took place in 1480 between Eleanor, sister of the eighth earl of Kildare, and Conn Ó Néill, son of Énrí Ó Néill 'captain of his nation'. ${ }^{8}$ The Ó Néill family were the most powerful in Ulster and, indeed, the most influential Irish family for much of the fifteenth and sixteenth centuries. ${ }^{9}$ Both of these families were, then, very wealthy and influential; as was the case with marriages between English, or between Irish people, intermarriage tended to occur between people of similar social standing. The eighth earl also married two of his six daughters from his first marriage to powerful Irishmen; his daughter Eleanor married first Domhnall MacCartaigh, Ruadh of Desmond, then Calbhach Ó Domhnaill of Tyrconnell, and his daughter Alice married her cousin Art Og Ó Néill of Tyrone. ${ }^{10}$ Oliver Fitzgerald of Belagh (modern County Westmeath), son of the eighth earl, married Meadhbh, daughter of Cathaoir Ó Conchobhair at the start of the sixteenth century. ${ }^{11}$ The earl was, as noted by Steven Ellis, ${ }^{12}$ criticised by his opponents for contracting such marriages and being allied so closely with the Irish, as these activities were forbidden by statute and frowned upon by some members of the colonial community. ${ }^{13}$ However, the earls and their relatives deftly used marriage to garner allies in both Irish and English spheres, and it was in part this versatility which enabled them to exert so much power over Irish affairs. $^{14}$

Inter-ethnic marriages among the elite are well known, as the elite are the focus of much primary and secondary literature, but less elevated English men and women also married Irish people. These marriages have long been acknowledged, but never explored in detail. The survival of ecclesiastical court records and documents of municipal bodies from the fifteenth century enables us to assess the prevalence of inter-ethnic marriage among the gentry and townspeople of the four counties and discuss individual instances of intermarriage in some depth. It is unfortunately not possible to go much further down the social scale: members of the gentry and citizens of towns appear in the sources with some regularity, but information about the names and marital partners of the less wealthy, largely rural tenant farmers and labourers who comprised a large part of the population is almost entirely absent from the documentary record. This is due both to the tendency of the sources to record financial and legal transactions that occurred between people of means and to the creation of records by municipal bodies that ensures that there is more evidence relating to urban communities than rural ones.

parliament of Ireland: Edward IV (2 vols, Dublin, 1914), vol. 1, 487-9; Edward Tresham, Rotulorum patentium et clausorum cancellariae Hiberniae calendarium (Dublin, 1828), 270.

${ }^{8}$ Berry and Morrissey, Statute rolls...Edward IV, vol. 2, 87.

${ }^{9}$ The extent of their influence is clear in many surviving documents, including the registers of the archbishop of Armagh, which show that various archbishops throughout the fifteenth century attempted over and over to negotiate with them, and stop their constant attacks on church tenants in Ulster: Katharine Simms, 'The archbishopric of Armagh and the O’Neills', IHS 19 (73) (1974), 38-55. The Uí Néill continued to be one of the most important of all Irish families, as evidenced by Queen Elizabeth’s negotiations with Seán and Aodh Ó Néill in the late sixteenth century: Ciaran Brady, Shane O'Neill (Dundalk, 1996).

10 Steven G. Ellis, 'Fitzgerald, Gerald, eighth earl of Kildare (1456?-1513)', Oxford Dictionary of National Biography (Oxford, 2004, online edn, Jan 2008). Available at: http://www.oxforddnb.com/view/article/9554 (accessed 27 May 2011).

${ }^{11}$ K.W. Nicholls, 'The descendants of Oliver FitzGerald of Belagh', Irish Genealogist (hereafter IG) 4 (1) (1968), 2-8: 2-3, 5.

12 Steven Ellis, 'A crisis of the aristocracy? Frontiers and noble power in the early Tudor state' in John Guy (ed.), The Tudor monarchy (London, 1997), 330-9: 337.

${ }^{13}$ Patrick Finglas, 'The decay of Ireland', J.S. Brewer and William Bullen (eds), Calendar of Carew MSS (6 vols, London, 1869-73), vol. 1, 3.

${ }^{14}$ Edmund Curtis famously called the eighth earl the 'the real king of Ireland'. This was an overstatement, but he was indeed the foremost magnate in Ireland at the end of the fifteenth century, although, as Steven Ellis has argued, the English crown did not necessarily resent his power, but rather used him to govern Ireland with as little cost to the English exchequer as possible: Edmund Curtis, A history of medieval Ireland (Dublin, 1927), 385; Steven Ellis, 'Tudor policy and the Kildare ascendancy in the lordship of Ireland 1495-1534', IHS 20 (79) (1977), 235-71. 


\section{Names and ethnic origin}

Even for those gentry and townspeople who do appear in the sources, there is often very little information. Generally, we know little about these more humble individuals, and their names are often the only way to determine whether they were 'English' or 'Irish'. These categories were not based solely on descent but also on cultural, political and legal attributes, and some number of anglicised individuals who were of Irish descent may have been considered 'English' ${ }^{15}$ By the fifteenth century, however, descent was the most important factor in determining whether a given person was considered 'English' or 'Irish' and it could trump both legal and cultural considerations. ${ }^{16}$ In this period the Irish could, and did, purchase grants of English law and it did not automatically make them 'English', while English nobles could speak Irish and patronise Irish bardic poets and it did not make them 'Irish', but rather 'degenerate' or 'rebel' Englishmen. ${ }^{17}$ Thus surnames, which inform us of the patrilineal descent of individuals, are not only often the sole evidence that is available to determine ethnic identity, they are some of the most useful. ${ }^{18}$ Names can, furthermore, shed some light on the cultural aspects of 'Englishness' and 'Irishness'; first names, nicknames, and variant surname forms, like the inclusion or exclusion of the Irish ' $\mathrm{O}$ ' and 'Mac' patronymics, can reveal the extent to which a given individual was culturally anglicised or gaelicised.

It is not always simple to determine ethnic origin using surnames, and two examples from County Louth illustrate some of the difficulties that names can present. In 1426, the archbishop of Armagh, John Swayne, ordered the people of his diocese to stop accusing Richard Heyne (Ó hEidhin) of Drogheda of having beaten his wife, Clarys White, to death. ${ }^{19}$ The surname White was common in medieval Ireland and it can be difficult to be certain whether it is English or Irish, and thus to determine whether Heyne and White's marriage was an inter-ethnic one. There was a White family of Louth who moved into Ulster and became the barons of Dufferin in the early fifteenth century; ${ }^{20}$ although they were perhaps somewhat gaelicised, they were of English ethnicity. ${ }^{21}$ However, not all

\footnotetext{
${ }^{15}$ The Irish population resident in the late twelfth century may have automatically been given access to English law if they were freeholders, and it's possible that some of their descendants were fully assimilated - these Irish people would be very difficult to trace in the sources as many would have taken English names and have been treated as English people, but the Betaghs of Meath, and perhaps the Donoghs and Kellys of Dublin may have been such families: Frame, 'Les Engleys nées en Irlande', 87; K.W. Nicholls, 'Anglo-French Ireland and after' in Peritia 1 (1982), 374; Sparky Booker, 'Gaelicisation and Identity in the 'four obedient shires' of Ireland, 1399-1534', Ph.D thesis (Trinity College Dublin, 2011), 80-5, 180-1.

${ }^{16}$ The debate about what elements comprised English and Irish identity is long running-Robin Frame and Steven Ellis have emphasised access to English law and government as constitutive of Englishness, but have also acknowledged the importance of ancestry: Robin Frame, English lordship in Ireland, 1318-1361 (Oxford, 1982), 134; Frame, 'Les Engleys nées en Irlande', 85-6, 89. Ellis, 'Racial discrimination', 22-3.

${ }^{17}$ For more on the importance of descent over cultural attributes for determining Englishness in the fifteenth century, see Booker, 'Gaelicisation and identity', 280-5.

${ }^{18}$ The designation 'English' referred to anyone from the settler community, and many of these individuals were of Welsh, Scottish, Flemish, or part-Irish ancestry. 'Irish' encompassed many of part-Scottish and English descent.

${ }^{19}$ D.A. Chart, The register of John Swayne, archbishop of Armagh, 1418-1439 (Belfast, 1935), 43.

${ }^{20}$ In 1392 a member of this family, Geoffrey White, was a keeper of the peace for County Louth and was killed defending it from the attack of Niall Óg Ó Néill. After the revolt of 1404, the family took over 'the dominant position within the Ulster colony': Katharine Simms, 'The Ulster Revolt of 1404-an anti-Lancastrian dimension?' in Brendan Smith (ed.), Ireland and the English world in the late middle ages (Basingstoke, 2009), 141-60: 147, 155.

${ }^{21}$ The Whites entered into various familial relationships with the Irish, such as the aforementioned marriage of Clarys White to Richard Heyne and that of Alice White, an English girl, in c. 1426 to Roger Mccmachuna (Mac Mathghamhna) of Clogher: Chart, Register of John Swayne, 45-6. Two women bearing the name White, likely members of this English family, were in relationships with leading members of the Ó Neill family in 1451: Isobel White was the wife of 'Mauricius' Ó Neill, and Roys White the concubine of Muircheartach Ruadh Ó Neill Bhuidhe: W.G.H. Quigley and E.F.D. Roberts, Registrum Iohannes Mey: the register of John Mey, archbishop of Armagh, 1443-1456 (Belfast, 1972), 218-19, 222-4. Additionally, James White sought and was granted a licence to foster his children in the house of Muircheartach Ó Neill in 1410: Simms, 'Ulster Revolt', 154.
} 
individuals who bore the surname 'White' were of English descent. In 1434 John Whyt (White) was in possession of the rectory of St Mary's in Painestown, County Meath, and an entry in the papal letters includes his alias, 'Brugan'. ${ }^{22}$ This is the Irish name Ó Brógáin; it seems that John dropped this family surname in favour of the English Whyt/White or at least that he used both names. This use of aliases and variant names makes the study of surnames even more difficult, although many sources from the colony took care to record the various aliases of the people they discuss. ${ }^{23}$

The use of the surname 'White' by both the English and Irish can be partially explained by the enactment of the Irish parliament in 1465 which ordered any Irishman living among the English

in the counties of Dublin, Meath, Uriell [Louth], and Kildare...[to] take unto himself an English surname of a town, as Sutton, Chester, Trim, Skreen, Cork, Kinsale; or a colour, as White, Black, Brown; or an art, as Smith or Carpenter; or office, as Cook, Butler, and that he and his issue use that name under pain of forfeiture of his goods yearly. ${ }^{24}$

It is impossible to establish the percentage of Irish men and women who obeyed the mandates of this legislation, but there are many examples of Irish people using English surnames, particularly descriptive surnames like White and Brown, and occupational ones like Smith and Butcher. For example, it is likely that Dermot (Diarmait) Taillor, Malachy Corryser, Dermot (Diarmait) Carryk and Laughlin (Lochlainn) Boucher, all of whom appear in later fifteenth-century records from Dublin, were Irish, as each of them bore an Irish first name and an occupational or toponymic surname. ${ }^{25}$ Though the Irish of the four counties often adopted English first names, the reverse was very rare, and thus these four men were almost certainly Irishmen by descent who had jettisoned their original Irish surname in favour of an English-sounding one. This is not to suggest that these men were reacting directly to the 1465 statute, as the process of anglicisation which encouraged many Irishmen to take English toponymic, occupational, or descriptive surnames was well underway by the mid-fifteenth century. ${ }^{26}$ This adoption of English names by the Irish led to a situation whereby some individuals who seem from their surnames to be English, were in fact of Irish descent (patrilineally, at least), and we must be aware of this possibility when using surnames to determine ethnicity. In the particular case of Clarys White, it is more likely she was of English descent than Irish. Her first name is English, and the English Whites were based in the Louth/South Ulster area, near Clarys' home in Drogheda. ${ }^{27}$ Additionally, a far greater number of men and women bearing the name 'White' and living in these four counties seem to have been English, and without evidence to the contrary, one must, cautiously, treat them as such.

Another person from County Louth with a somewhat confusing name was Mordagh McKenedy, husband of Matilda Tunlyn, who leased land from Christopher Dowdall in 1476. ${ }^{28}$

\footnotetext{
${ }^{22}$ William H. Bliss, J.A. Tremlow et al. (eds), Calendar of papal registers relating to Great Britain and Ireland (14 vols, London, 1906), vol. 8, 511.

${ }^{23}$ The official governmental documents and legal documents used throughout this paper were most likely to record names and aliases accurately, as it was vital for legal purposes to know precisely who people were: J.C. Holt, What's in a name? Family nomenclature and the Norman conquest (Reading, 1981), 6.

${ }^{24}$ Berry and Morrissey, Statute rolls...Edward IV, vol. 1, 291.

${ }^{25}$ Henry F. Berry, Register of wills and inventories of the diocese of Dublin in the time of Archbishops Tregury and Walton, 1457-1483 (Dublin, 1897), 68, 138; Colm Lennon and James Murray (eds), The Dublin city franchise roll, 1468-1512 (Dublin, 1998), 33.

${ }^{26}$ However, not all adopted names were toponymic, occupational, or descriptive. A painter named Alexander FitzJohn was admitted to the franchise of Dublin city in 1469 but struck off in 1490 'because he is of the Irish nation and for other crimes and offences'. The surname FitzJohn is Norman in form, and there was a branch of the Geraldines who used this surname occasionally, but there was a FitzJohn family, also called MacShane, that was of Irish descent: Lennon and Murray, Franchise roll Dublin city, xxvii. The FitzGeralds who were also called FitzJohn were mostly descendants of a son of the eighth earl of Kildare: Lord Walter FitzGerald, 'Fitzgeralds of Ballyshannon (Kildare) and their successors thereat', Journal of the County Kildare Archaeological Society and Surrounding Districts 3 (7) (1902), 427.

${ }^{27}$ See notes 20 and 21.

${ }^{28}$ Charles McNeill and A.J. Otway-Ruthven (eds), Dowdall deeds (Dublin, 1960), 198.
} 
Although Mordagh's name looks Irish, it is likely that he was in fact Scottish. ${ }^{29}$ The name 'Mordagh' may be a version of 'Murdoch' or 'Murtagh', a first name used by the Scottish MacKennedys of Carrick in the thirteenth and fourteenth centuries. ${ }^{30}$ Kennedy is of course also the name of the Ó Cinnéide family, a branch of the Munster Ó Briain lineage, but Kennedy with the 'Mac' rather than ' $\mathrm{O}$ ' prefix is Scottish in origin. The Scottish MacKennedys may have been related to the Ulster dynasty of Ó Néill, and there is evidence that they spoke Scots Gaelic. ${ }^{31}$ It would be very interesting to know, in light of this, whether Mordagh was perceived as an Englishman or an Irishman in fifteenth-century County Louth, or whether the colonial community was alive to more subtle designations. ${ }^{32}$ Mordagh did not fit neatly into the English/Irish dichotomy that characterises documents from this period, and his presence in County Louth reminds us that, on the ground, these communities were complex and could not always be clearly divided. Regardless of the difficulties names can present, they are the most numerous and useful markers of ethnicity that have survived, and a study of inter-ethnic marriage cannot avoid using them. I have attempted to determine the most likely origin of the surnames contained in this paper as accurately as possible, using a range of information, including the geographical distribution of families, first names, and any other information provided by the sources.

\section{Interethnic marriages beyond the settler elite}

Keeping in mind these methodological concerns, we return to the question of the prevalence of interethnic marriage in the heart of the English colony, particularly among the less studied, more humble segments of settler society. Art Cosgrove and Gillian Kenny have written the most extensive assessments of intermarriage in medieval Ireland, but only as small parts of larger, broader studies. Cosgrove did not address the geographical distribution of such marriages within the colony, nor the chronological spread. He argued that intermarriage did occur, despite the social pressure against it, but only discussed one specific case. ${ }^{33}$ Kenny's larger and more detailed study addresses the geographical spread of intermarriage, and she concludes that 'the majority of intermarriages between Gaelic and Anglo-Irish took place far from the centre of English administration in Dublin. The closer one approached to Dublin and its hinterland, the harder it gets to find examples of Gaelic and Anglo-Irish families intermarrying. ${ }^{34}$ It was the case, as Kenny argues, that such marriages were more common in the most gaelicised areas of the colony; however, she may underestimate the prevalence of intermarriage within the 'English' east of the colony.

So just how prevalent was inter-ethnic marriage in counties Dublin, Meath, Louth and Kildare? It is not possible quantitatively to answer this question, as the difficulty in making secure surname identifications makes the statistics necessarily inexact. We know that some Irish people had, by the fifteenth century, begun to adopt English-sounding names, and this could lead to a significant under-calculation of inter-ethnic marriages. Additionally, the failure of the sources to systematically record women's surnames or maiden names makes it impossible to establish the ethnicity of many

29 The Scottish MacKennedy family are the subject of a very extensive research project headed by Iain Kennedy: www.kennedydna.com (accessed 26 January 2012).

${ }^{30}$ Hector MacQueen 'The kin of Kennedy, 'Kenkynnol' and the common law', in Alexander Grant and Keith Stringer (eds), Medieval Scotland: crown, lordship and community (Edinburgh, 1993), 274-96: 282; Colm McNamee, The wars of the Bruces (Phantassie, East Lothian, Scotland, 1997), 169, 171.

31 G.W.S. Barrow, Robert the Bruce and the community of the realm of Scotland (Edinburgh, 2005), 34; MacQueen, 'The kin of Kennedy', 279.

32 The identity of Scottish people in Ireland is an interesting issue. In 1297, Henry Scot was found to be of Scottish descent and, therefore, was legally 'English', and entitled to English law. It is difficult to know how Scottish people would have been perceived by the fifteenth century, after the Bruce invasion of Ireland and their alliance with several Gaelic lords, especially if they displayed some outwardly Gaelic characteristics like language, as Mordagh may have: David Ditchburn, 'Who are the Scots? Some problems of identification and misidentification in later medieval Europe' in Paul Dukes Lewiston (ed.), Frontiers of European culture (New York, 1996), 89-100: 92.

${ }^{33}$ Art Cosgrove, 'Marriage in medieval Ireland' in Art Cosgrove (ed.), Marriage in Ireland (Dublin, 1984), 2550 .

${ }^{34}$ Gillian Kenny, Anglo-Irish and Gaelic women in Ireland, c. 1170-1540 (Dublin, 2007), 86-91. 
women. To add to these difficulties, the sources for Ireland only mention marriage and name married couples tangentially, in the course of recording legal proceedings, land transactions and similar events. There is no source that methodically recorded marriages as part of its raison d'être. Thus, records of marriages survive randomly and there is not a great deal of total data available.

And yet, some attempt at quantifying this data, however tentative, may be helpful. If we look only at the marriages found within a single source and determine the percentage of these that are interethnic, it can provide a very rough idea of their prevalence. In the records of the Dowdall family of Louth from the fifteenth century, 39 married couples are mentioned, and of these two, 5.1per cent of the total, were mixed. In the register of Primate Swayne, which contains mostly marriages from Louth, 6 out of 29 (20.7per cent) total marriages recorded were inter-ethnic. In Dublin, the franchise rolls contain records of 70 marriages, of which 9 were mixed (12.9per cent). Generally these small but significant percentages of mixed marriages are replicated in the other sources for this study area. Given that there are a number of marriages where the ethnicity of either or both partners could not be ascertained, and that there was extensive anglicisation of Irish names, these percentages are conservative and the true incidence of the practice was probably higher. Inter-ethnic marriage, then, was not an aberration but rather part and parcel of colonial society in the heartland of the colony. This was in spite of the frequent enactments against intermarriage, and the various social and legal barriers that militated against such unions. ${ }^{35}$

\section{Prohibitions and penalties for intermarriage}

There was considerable social and legal pressure against intermarriage, and it increased as the fourteenth century progressed, suggesting perhaps that the practice was common and becoming increasingly more so. An enactment against marriage between English marchers and Irish individuals who were at war with the crown had been suggested to Edward II in the second decade of the fourteenth century. ${ }^{36}$ In 1347, members of the colonial administration advised Edward III to prohibit the English of Ireland from marrying the Irish without the express permission of the king or his deputy, and in 1351 a ban was put in place against the marriage of loyal English subjects to 'English or Irish enemies of our lord the king' ${ }^{37}$ This ban was not anti-Irish per se, as it proscribed marriage with English 'enemies' as well as Irish ones; rather, it sought to impose a social barrier between enemies of the king, English or Irish, and his loyal subjects. In 1357 the mention of the king's consent was omitted, as was any mention of 'English enemies', and all marriages of marchers to Irish people were prohibited. ${ }^{38}$ The ban was justified with the assertion that the Irish spied on the colony and gained important information about the military actions of the Dublin government through their familial contacts in the English community.

In 1366, in the famous 'Statutes of Kilkenny', the enactment against intermarriage was again quite general, without the qualification 'enemy', and it extended to all Irish people (Irrois), not just those who were enemies of the king. ${ }^{39}$ The parliament did not offer a strategic or military justification like that given in 1357, but rather seemed to assume that such unions, and the assimilation that they facilitated, were patently and inherently undesirable. Moreover, the sanction for entering into these unions was extremely severe-a charge of treason. It could be argued that the presence of Lionel of Clarence, son of the king of England, at the parliament in 1366 may have led to the greater harshness in the legislation against interaction with the Irish. However, the Irish parliament frequently re-issued the legislation of 1366 in the following decades and throughout the fifteenth century, indicating both that they supported the enactments made in Kilkenny and that intermarriage continued to take place

\footnotetext{
${ }^{35}$ Gillian Kenny notes that there was no effective way to enforce such legislation, and that it was frequently ignored: Anglo-Irish and Gaelic women, 88.

${ }^{6}$ J.A. Watt, 'The Anglo-Irish colony under strain' in Art Cosgrove (ed.), A new history of Ireland, (11 vols, Dublin, 1993) vol. 2, 352-96: 383-84; Gearóid Mac Niocaill, Na Buirgéisí (3 vols, Dublin, 1964), vol. 2, 336.

${ }^{37}$ G.O. Sayles, Documents on the affairs of Ireland before the king's council (Dublin, 1979), 188-9; Henry F. Berry (ed.), Statute rolls of the parliaments of Ireland: King John to Henry V (Dublin, 1939), 387.

${ }^{38}$ Berry, Statute rolls...King John to Henry V, 412.

${ }^{39}$ Berry, Statute rolls...King John to Henry V, 433.
} 
regardless of the prohibitions against it. ${ }^{40}$ In 1430 , in one such reiteration, the more specific term 'Irish enemies' was again used, although it is difficult to say if this meant that some Irish people were exempt from 'enemy' status, or whether, at this point, the parliament was using the common formula of 'Irish enemy' to mean all Irish people. ${ }^{41}$

The prohibitions against intermarriage often extended to other personal ties like fosterage, demonstrating the view held by some members of the English community in Ireland that such associations were detrimental to the colony, as they led, it was believed, to 'degeneracy' - the adoption of Irish customs. ${ }^{42}$ This was very likely true, and many Irish practices probably entered settler society via marriage, but as Seán Duffy and others have argued, such cultural exchange went both ways, and these marriages also facilitated anglicisation among the Irish. ${ }^{43}$ This may be why so many of the Irish individuals discussed below dropped the tell-tale Irish ' $O$ ' prefix from their surnames; their marriage into and connections with English society may have encouraged this particular form of anglicisation.

In addition to these parliamentary prohibitions, some English people may have hesitated to marry Irish people and have half-Irish children because the children's Irish ancestry could be used against them in legal proceedings and thus make their life in the four counties more difficult. ${ }^{44}$ The records of detailed inquisitions into the ancestry of various individuals survive from this period, and if the jurors found that the individuals under examination were Irish, appeals were usual. This suggests that the subjects of these inquisitions were unwilling to let the accusation of Irish blood stand. One such appeal occurred in 1459, when two clerics from Meath, John Ardagh and John Cadegan, were accused of being Irish and found to be so by an inquisition, to their 'great ruin'. The men requested a second inquisition to clear their names and it found that 'all their ancestors are and were English and of the English nation and not Irish, as is supposed by the said inquisition'. The Irish parliament ordered that all record of the first, damning inquisition be expunged and that Ardagh and Cadegan were never to be found to be 'Irish, contrary to their blood' in the future. ${ }^{45}$

The ethnicity of Adam Nores of Drogheda was examined in $1384,{ }^{46}$ and that of Richard Kevenok of Lusk, whose surname has a superficial resemblance to the Irish 'Caomhánach', in $1465 .{ }^{47}$

\footnotetext{
${ }^{40}$ For an exhaustive list of re-issuings of the statutes of Kilkenny, see Peter Crooks, “"Hobbes”, "Dogs” and politics in the Ireland of Lionel of Antwerp, c. 1361-6’, Haskins Society Journal 16 (2005), 121, note 18.

${ }^{41}$ Berry, Statute rolls...Henry VI, 31.

${ }^{42}$ The use of Irish customs, even just hairstyles or dress, was a deeply political issue; it was believed that taking on these cultural attributes would lead to disloyalty and political alienation from England. Conversely, Irishmen who wished to become politically and legally English were expected to conform in matters of hairstyle and dress. Historians have shown that this was not in fact the case, and that many Englishmen who were gaelicised in appearance remained loyal to the king of England, but for both the English of England and those of Ireland, 'degeneracy' was an important political issue. The proliferation across Europe in this period of sumptuary legislation that regulated the dress of different social and ethnic groups in society shows that they were not alone in this view: Berry, Statute rolls...King John to Henry V, 431; Frame, 'Les Engleys nées en Irlande', 95; Christopher Maginn, 'English marcher lineages in south Dublin in the late middle ages', IHS 34 (134) (2004), 113-36: 136; Robin Frame, 'Power and society in the lordship of Ireland 1272-1377' in Ireland and Britain, 191-220: 215-17; Alan Hunt, Governance of the consuming passions: a history of sumptuary law (London, 1996).

43 Seán Duffy, 'The problem of degeneracy' in James Lydon (ed.), Law and disorder in thirteenth century Ireland: the Dublin parliament of 1297 (Dublin, 1997), 87-106: 89-90; Freya Verstraten 'Naming practices among the Irish secular nobility in the high middle ages', Journal of Medieval History 32 (2006), 43-53; Robin Frame, 'Review of James Muldoon, Identity on the medieval Irish frontier: degenerate Englishmen, wild Irishmen, middle nation', English Historical Review , 119 (2004), 1029-30.

${ }^{44}$ Steven Ellis, 'Racial discrimination in late medieval Ireland', in G. Hálfdanarson (ed.), Racial discrimination and ethnicity in European history (Pisa, 2003), 21-35; A.J. Otway-Ruthven, 'The native Irish and English law in medieval Ireland', IHS 7 (25) (1950), 1-16: 14. Reprinted in Peter Crooks (ed.), Government, war, and society in medieval Ireland (Dublin, 2008), 141-154.

${ }^{45}$ Berry, Statute rolls...Henry VI, 619-23. Cadegan is a Welsh toponymic, so this man was not of Irish descent, at least patrilineally. Ardagh is also a toponymic surname, which means that it may be either Irish or English.

${ }^{46}$ McNeill and Otway-Ruthven, Dowdall deeds, 290. This is probably le Norreys or Norreys, meaning either 'northman', referring to those from northern England, or 'of Norwich'. William Nories held land in Carlow in the late twelfth century, and was a witness to several grants made to the abbey of St Thomas in Dublin around
} 
Davy Grenan, vicar of Timoole, County Meath, whose name resembles 'Ó Grianáin’, was subject to an inquisition in $1476^{48}$, as was Richard Lynane, rector of Mychelistown in $1516 .{ }^{49}$ Nowhere in the accounts of these inquiries was there any examination of the habits, customs, or character of the men in question; rather, they were more or less solely concerned with their ancestry, highlighting the primary importance of descent in colonists' conceptions of 'Englishness'. Interestingly, in each of these inquisitions the jurors found that the persons under examination were English, either initially, or on appeal, even though some of their surnames suggest that they may have in fact been of Irish descent. ${ }^{50}$ Perhaps these men who were accused of being Irish ensured a favourable verdict for their appeals, either by bribery or some kind of social or political pressure.

It is clear that the English of Ireland were deeply concerned with proving their English ancestry, and that there was a serious stigma associated with 'Irish blood'. ${ }^{51}$ The wording of a statute enacted by the Irish parliament in 1467 is particularly telling. In this year, Robert FitzEustace was the constable of the castle of Ballymore (Ballymore Eustace, Co. Kildare), and instead of residing there he instituted a sub-constable, Laurence Obogan (Ó Bogáin). ${ }^{52}$ Obogan was, according to the parliament, 'an Irishman and of the Irish nation, on the side of his father and mother, who by nature of blood betrays the secrets of Englishmen'. ${ }^{53}$ Accordingly, FitzEusace was ordered to replace Obogan with an Englishman and to never again employ Irishmen at the castle. This pre-occupation with descent and bloodline may account for the social pressure against intermarriage, as was evident in Stakallon, Co. Meath where Mabina Huns, wife of John Brogeam, sought a divorce in 1448 on the grounds that John had previously been pre-contracted to an Irish woman named Katherine Oduboy. At the insistence of his friends, who did not approve of his union with an Irish woman, he had broken this pre-contract and married Huns instead. ${ }^{54}$

There were also economic punishments put in place to discourage these forbidden unions, namely, the confiscation of land. The lands of Elizabeth la Veel/Calf, who famously wed Art Mac Murchadha Caomhánach, self-proclaimed 'King of Leinster', were confiscated c. $1390 .{ }^{55}$

this time. John and Jacob Norries were also witnesses to early grants made to the abbey. Although the family had land in Carlow, there were Norreys in Dublin by the early fourteenth century as one Richard Norreys was a witness to a land transaction in Dublin in 1313: J.T. Gilbert, Register of the abbey of St Thomas Dublin (London, 1889), 111-3, 117-8, 161, 208, 308-9, 368; M.J. McEnery and Raymond Refaussé, Christ Church deeds (Dublin, 2001), 138; P.H. Reaney and R.M. Wilson, Dictionary of English surnames (Oxford, 2005), 324; Patrick Hanks, Flavia Hodges, A.D. Mills, Adrian Room (eds), Oxford names companion (Oxford, 2002), 454.

${ }^{47}$ Berry and Morrissey, Statute rolls...Edward IV, vol. 1, 377.

${ }^{48}$ Berry and Morrissey, Statute rolls...Edward IV, vol. 2, 521.

${ }^{49}$ Mario Alberto Sughi, The register of Octavian de Palatio, archbishop of Armagh, 1478-1513 (Dublin, 1999), 31. Lyneham is, according to Patrick Hanks and Flavia Hodges, A dictionary of surnames (Oxford, 1988), 337, a habitation name from southern England, and if Richard Lynane was indeed English, this is probably his true surname. It also bears a resemblance to the Irish names 'Ó Laigheanáin' and 'Ó Leannáin'. The colonists who mistook these men for Irishmen (if this was indeed a mistake), display, in doing so, their own familiarity with Irish names.

${ }^{50}$ Five out of six of these men were clergymen. This may be due to the parliamentary ban on Irish clerics holding benefices in the colony; disputes over benefices were common and one claimant might discredit the other with an accusation of Irish blood. The accusation against Nores, a layman, seems to have arisen in the course of a land dispute, and was presumably used as a way for his opponents to discredit him.

${ }^{51}$ The power of such accusations was acknowledged by the regulations of several towns which ruled that falsely calling someone Irish was slanderous, and a false or unproven accusation of Irishness could lead to imprisonment: Geoffrey Hand, 'The status of the native Irish in the lordship of Ireland, 1272-1331', The Irish Jurist (new series) 1 (1966), 93-114: 104; Herbert Wood, Albert E. Langman and Margaret C. Griffith (eds), Calendar of justiciary rolls Ireland, 1295-1303 (3 vols, Dublin, 1905-56), vol. 1, 18, 390.

${ }^{52}$ Laurence may have been a member of the Ó Bogáin family of Wexford: MacLysaght, The surnames of Ireland (Dublin, 1997), 20.

${ }^{53}$ Berry and Morrissey, Statute rolls...Edward IV, vol. 1, 585 (my italics).

${ }^{54}$ TCD MS 557, The register of Archbishop Prene, transcribed by Bishop Reeves, (vols 5 and 6), 214; Cosgrove, 'Marriage in medieval Ireland', 35.

${ }^{55}$ Cosgrove, 'Marriage in medieval Ireland', 35; Kenny, Anglo-Irish and Gaelic women, 37; Lord Walter FitzGerald, 'Narraghmore and the barons of Norragh', Journal of the County Kildare Archaeological Society and Surrounding Districts 7 (4) (1913), 242-65: 251; Edmund Curtis and E. St John Brooks, 'The barons of 
Enforcement was not consistent, and many of those who married Irish individuals do not seem to have suffered this fate. Presumably la Veel was punished in this way because her chosen husband represented a powerful threat to crown power in the colony. ${ }^{56}$ MacMurchadha did not accept the confiscation, and attacked the colony, ending his attacks only when the lands were restored to him and his wife, upon his submission to Richard II. ${ }^{57}$ MacMurchadha was an excellent example of what the parliament feared when noble English women, particularly wealthy ones, wed powerful Irish men, and provided them with lands and a foothold in the four counties - he did not adhere to his submission to Richard II, and resumed his attacks on the colony. ${ }^{58}$

The lands of Katherine Byron of Rathbeggan, Co. Meath, were confiscated by the Irish parliament of 1472-3 because she married Esmond Deshe (Déise), an Irishman. ${ }^{59}$ The parliament determined that, as Esmond was 'an Irishman and of the Irish nation, that is to say, of the Deshes enemies to our said sovereign', 'all the said messuages, lands and tenements' belonging to Katherine 'are seized into the hands of our sovereign lord the King' ${ }^{60}$ The seizure of her land was reversed in 1474, but frustratingly, the parliament rolls record only that this was due to 'divers considerations had in the last said Parliament', so we do not know the specifics of their deliberations. ${ }^{61}$ The parliament did not, it seems, enforce the regulations against intermarriage in cases in which the English partner held little or no land, or if the Irish partner was not considered an 'enemy'. Such confiscations were not as relevant for Englishmen marrying Irish women, as their gender ensured that they retained their lands and that they did not pass into Irish hands. (That is, if one does not consider as Irish the halfIrish children that would result from such a union.) These confiscations could be viewed as, in effect, an extension of the prohibitions occasionally put in place against granting land to Irish individuals. ${ }^{62}$ However, the confiscation of land was also used as punishment when men of the colonial community married Irish women, as the lands of Edward Nugent of Ballebrannagh, Co. Meath, were seized into the king's hands in 1520 when he married Owyn Niny Molloy (Úna (?) Iníon Uí Mhaoilmhuaidh), an 'Irish enemy'. ${ }^{63}$ Like Byron, Nugent managed to have the decision reversed, and regained his property. ${ }^{64}$

Nugent, an Englishman marrying an Irish woman, suffered the same punishment as la Veel and Byron when they married Irishmen. Despite the fact that English womens' lands might come under the control of their Irish husbands, the prohibitive legislation did not penalise the marriage of Irishmen to English women more harshly than the marriage of Englishmen to Irish women. In many colonial societies, the pattern of intermarriage is that men from the settler culture marry or have sexual relationships with native women, but the reverse is rare ${ }^{65}$ This may be related to the fact that

Norragh, Co. Kildare, 1171-1660', Journal of the Royal Society of Antiquaries of Ireland, Seventh series, 5 (1) (1935), 84-101: 89-90.

${ }^{56}$ Mac Murchadha's son also married into an important noble English family from the colony, as his wife was Aveline Butler, sister of the earl of Ormond: Emmett O’Byrne, 'Cultures in contact in the Leinster and Dublin marches, 1170-1400' in Seán Duffy (ed.), Medieval Dublin V (Dublin, 2004), 111-48: 145. For the (MacMurrough) Kavanaghs see K.W. Nicholls, 'The Kavanaghs, 1400-1700', IG 5 (1974-9), 435-47, 6 (19803), 189-203.

${ }^{57}$ For Mac Murchadha's negotiations with Richard II and an exploration of his power in Leinster, see Robin Frame, 'Two kings in Leinster: the crown and the MicMhurchadha in the fourteenth century' in T.B. Barry, Robin Frame, and Katharine Simms (eds), Colony and frontier in medieval Ireland (London, 1995), 155-75.

${ }^{58}$ Frame, 'Two crowns', 172; Walter FitzGerald, 'Narraghmore and the barons of Norragh', 251.

${ }^{59}$ Edmund may be a member of the Déise family, an Irish Meath family who, MacLysaght argues, took their name from Deece in County Meath: MacLysaght, Surnames of Ireland, 77.

${ }^{60}$ Berry and Morrissey, Statute rolls...Edward IV, vol. 2, 147.

${ }^{61}$ Berry and Morrissey, Statute rolls...Edward IV, vol. 2, 241.

${ }^{62}$ Berry and Morrissey, Statute rolls...Edward IV, vol. 1, 415, 419-23, 511-3, 543, 549.

${ }^{63}$ Margaret C. Griffith, Calendar of inquisitions formerly in the office of the chief remembrancer of the exchequer, Co. Dublin (Dublin, 1991), 35; Kenny, Anglo-Irish and Gaelic women, 89-90.

${ }^{64}$ Kenny, Anglo-Irish and Gaelic women, 89.

${ }^{65}$ In the English colony in France in the first half of the fifteenth century English men married local women more often than the reverse, and the same was true among the Vikings in Ireland in the ninth and tenth centuries. In the modern period, in colonial America, in the Dutch East Indies in the seventeenth and eighteenth centuries, and in British India, the same pattern held true: Robert Massey, 'Lancastrian Rouen: military service and property holding 1419-49', 269-286; Anne Curry, 'Sex and the Soldier in Lancastrian Normandy, 1415-1450', 
colonies were often settled initially by men, and thus they needed to draw on the local population for wives and sexual partners, but did not provide women for native men to marry. This was not the case in late medieval Ireland where the English community was well-established and produced sufficient numbers of women for settler men to marry. ${ }^{66}$ And yet, there are hints that English women's intermarriages may have been more problematic ${ }^{67}$-Eleanor FitzGerald felt it necessary to seek charters of English law for her Irish husband and any future children when she married c. 1480, but when James Butler and his Irish wife Sadhbh Cháomhánach sought reassurance about their sons' ability to inherit as legitimate heirs, their worry was not that their sons would be considered Irish, but only that they were born out of wedlock. ${ }^{68}$ Does this suggest that status did not pass equally from the maternal and paternal lines, and thus, that it may have been more detrimental for the children of a mixed marriage to have an Irish father than an Irish mother? There is conflicting evidence, as genealogies, heraldry, systems of inheritance, and the inquisitions into ethnicity, with their focus on surnames, all centred largely around patrilineal descent. And yet maternal lineage was not ignored; for example, the Irish constable of Ballymore castle was described as 'an Irishman and of the Irish nation, on the side of his father and mother, who by nature of blood betrays the secrets of Englishmen' ${ }^{69}$ An earlier case from Tipperary in 1295 shows that, if they petitioned for it, men may have been able to claim the right to English law and status through their mother's side, as well as their father's, but most grants of English law were passed from men to their direct heirs. ${ }^{70}$ Scientific thought from this period was divided on the issue of the relative roles of mother and father in conception, and Aristotelian ideas held that a child's character and form was shaped largely by their father, while followers of Galen posited a more equal role for both parents. Both schools of thought are preserved in manuscripts from England and Ireland from the late middle ages, but it is difficult to say whether this indicates that many people in the colony would have known about or subscribed to either of these views. ${ }^{71}$ Whatever the theoretical ideas about descent, what is certain is that both types of intermarriage routinely took place.

Reading Medieval Studies 14 (1988), 17-45: 25; Howard Clarke, 'Ethnicity and cultural identity in Dublin, 800-1200', lecture in the James Lydon Seminar series, Trinity College Dublin, delivered 16 February 2010; Kathleen DuVal, 'Indian intermarriage and Métissage in Colonial Louisiana', The William and Mary Quarterly 6 (2) (2008), 267-305; Ronald Hyam, Empire and sexuality: the British experience (New York, 1990), 92, 95, 115; Ann Laura Stoler, Race and the education of desire (Durham, NC, 1995), 42.

${ }^{66}$ In the English colony in Wales, as in Ireland, both types of intermarriage were practiced from the start of the conquest of Wales: Laura Radiker, 'Observations on cross-cultural names and name patterns in medieval Wales and the March’, Proceedings of the Harvard Celtic Colloquium 26/27 (2006/2007), 160-198: 193.

${ }^{67}$ Richard Stanihurst, writing in the 1570s, may have been influenced by this prejudice, as his assessment of intermarriage focused on such unions contracted between English women and Irish men, rather than vice versa. He asserted that 'these Anglo-Irish whom we have been describing have cut themselves off so completely from the Old Irish that the humblest of the colonists in the English province would not give his daughter in marriage to the noblest Irish lord': Richard Stanihurst, 'Description of Ireland', in Liam Miller and Eileen Power (eds), Raphael Holinshed, A chronicle of Ireland (Dublin, 1979), 145.

${ }^{68}$ Berry and Morrissey, Statute rolls...Edward IV, vol. 1, 487.

${ }^{69}$ Berry and Morrissey, Statute rolls...Edward IV, vol. 1, 585 (my italics).

${ }^{70}$ In 1295 a man from Tipperary was accused of being a 'hibernicus', meaning he was Irish (and perhaps of unfree status), so he could not plead in English courts. The man's mother obtained Ostman status for him: she may herself have been of Ostman descent, or perhaps she just paid for her son to have English law: G.J. Hand, English law in Ireland 1290-1324 (Cambridge, 1967), 211.

71 TCD MS 667 is a fifteenth-century manuscript from Ireland, comprised of somewhat eclectic material, although mostly on ecclesiastical matters. It is largely in Latin and contains the following lines, in which the male seed is the determining factor in the child's gender: 'Septem sunt cellule in matrice mulieris, tres in dextera et tres in sinistra et una in medio. Si semen ceciderit in dextera, filius erit, et si in sinestra, filia erit, et si in medio, ermofodricus erit et si semen ceciderit a dextera in sinistram uir feminalis erit et si cecederit a sinistra in dexteram, mulier virilis erit.' ['There are seven cells in the womb of women, three on the right, and three on the left and one in the middle. If semen should fall on the right, it will be a son, and if it should fall on the left, it will be a daughter, and if it falls in the middle, it will be a hermaphrodite and if it should fall from the right into the left it will be womanly man, and if it should fall from the left to the right, it will be a masculine woman.'] Marvin Colker (ed.), Descriptive catalogue of the medieval and renaissance Latin manuscripts of Trinity College Dublin (2 vols, Dublin, 1991), vol. 2, 1123; Galen’s theories were known in early modern England, and 


\section{Intermarriage in Dublin}

The remarkable fact is that, despite these social, legal, and economic impediments to inter-ethnic marriages, they occurred in significant numbers, even in the most stridently English areas of the colony. That this was the case highlights yet again the wide gap that existed between the official rhetoric of the Dublin administration as expressed in legislation and the reality of life on the ground in medieval Ireland. Inter-ethnic marriage occurred across the four counties, in rural areas as well as in towns and cities, but as the source material is most abundant for urban areas, particularly Dublin and the towns of Louth, most of the couples discussed below lived in these areas.

In the city of Dublin and its immediate suburbs, some sixteen records of inter-ethnic marriages have been identified from the fifteenth century. While this may not sound like a high number, it is actually sizable, given that there are only occasional references to Dublin couples in the sources. The earliest records of intermarriage from the fifteenth century can be found in the register of Archbishop Alen of Dublin which records that Roger Bekeford, son of Elena Neell, gave his lands in 'Roleystown' and 'le Newestrete' in the liberty of St Sepulchre to the archbishop of Dublin in $1405 .{ }^{72}$ Bekeford's mother was an Ó Néill and of Irish descent, while the surname he bears is English, suggesting that his father was of English extraction. In 1421 the papacy granted plenary remission full forgiveness for a given sin-to a mixed couple: David Laffan of Dublin and his wife Samira Iniarele (this garbled Irish name is possibly the papal notary's spelling of 'Sadhbh Iníon Uí Raghallaigh'). ${ }^{73}$

After this, there is a gap of a few decades in the recorded examples of intermarriage in Dublin, before the numerous examples from the 1460s and 1470s. The sources are more numerous for the second half of the century, and records like the franchise roll of Dublin and testamentary records from the time of archbishops Tregury (1450-71) and Walton (1472-84), which are excellent for providing information about marriage, only cover the period from the late 1450s on. ${ }^{74}$ Accordingly, it is difficult to assess whether this rise in the records of such marriages reflects life on the ground, or if it is just a product of the uneven survival of source material. There does seem to have been increased Irish immigration into the colony in the fifteenth century, and perhaps an increased gaelicisation of some segments of the English community-an increase in the frequency of intermarriage-would make sense in such a context. ${ }^{75}$ It is likely that there was in fact both a slight rise in such marriages, and also that this increase is exaggerated by the chance survival of sources.

The next known mixed couple from Dublin appears in the records for 1462, as Juliana Loghlyn (Ó Lachtnáin or Ó Lochlainn?), who rented 'a void plot of ground' in Dublin in that year, was described as the widow of John Bicoll. ${ }^{76}$ The inventory of the goods of the Irish Dubliner Cecily

likely too in the English colony in Ireland: Bethan Hindson, 'Attitudes towards menstruation and menstrual blood in Elizabethan England’, Journal of Social History 43 (1) (2009), 89-114: 92.

${ }^{72}$ McNeill, Alen's register, 236.

${ }^{73}$ Bliss, Tremlow, et al., Calendar papal letters, vol. 7, 328. This man's first name, David, was not generally used by even anglicised Irish people, and Laffan may be the Norman 'La Font': Edward MacLysaght, More Irish families (Dublin, 1982), 142. Sadhbh was probably a member of the Ó Raghallaigh family, rulers of east Bréifne, modern Co. Cavan, who had frequent contact with the colonial community in the four shires: Katharine Simms, 'The O’Reillys and the kingdom of East Bréifne', Bréifne: Journal of Cumann Seanchais Bhréifne 5 (19) (1979), 305-19; Kieran Parker, 'The O’Reillys of East Bréifne, c. 1250-c. 1450', Bréifne: Journal of Cumann Seanchais Bhréifne 8 (2) (1991), 155-82.

${ }^{74}$ Many mixed marriages are preserved in the franchise rolls as marriage to a citizen was one way that many people gained the franchise for themselves.

${ }^{75}$ Steven Ellis has noted the rise in Irish tenants in Kildare over the fifteenth century and this process is equally evident in Louth. Tenant lists from these counties and jury lists from Meath and Dublin demonstrate the increase in the numbers of Irish inhabitants of the four counties as the fifteenth century progressed: Steven Ellis, Ireland in the age of the Tudors (London, 1998), 33; Booker, 'Gaelicisation and identity', 26-52.

${ }^{76}$ McNeill, Alen's register, 242. This is not the usual Irish version of O’Loughlin, but MacLysaght suggests that the Meath branch of O'Loughlins, of whom this Juliana is most likely a member, were originally O'Loughnane: MacLysaght, Surnames of Ireland, 198. Bic- is a common sound in English names, and it often means beekeeper, while it is not a usual sound in Irish names in either their Gaelic or anglicised forms: Reaney and Wilson, Dictionary of English surnames, 42-3. 
Langan (Ó Longáin) from 1473 shows that she was married to one William Walsch. ${ }^{77}$ 'Walsch' or 'Walsh' is a common surname among settlers meaning 'Welsh'; it was given to the descendants of Welshmen who participated in the invasion of Ireland in the late twelfth century. ${ }^{78}$ John Kerny (Ó Catharnaigh), a citizen of Dublin, was married to Margaret Fleming, and they served as executors for the will of Fleming's mother in 1483. ${ }^{79}$ 'Fleming' is a toponymic surname common among the early settlers in Ireland. It was used by colonists with Flemish origins, many, if not all, of whom came not directly from Flanders, but rather from the Flemish colony established by Henry I in south Wales. ${ }^{80}$ By the fifteenth century, and in an Irish context, it would have been considered a name from the English community. ${ }^{81}$

Nicholas Nangle, member of an established Meath/Kildare English dynasty, was admitted to the franchise of Dublin city in 1470 as his wife Johanna Ryan (Ó Riain) was a citizen. ${ }^{82}$ In 1475 Thomas Mulghan (Ó Maolagáin/Ó Maolachain) was admitted in right of his wife, Jenet Sowthren (Southern) and Richard Daynell by virtue of his marriage to Cecilia Colman (Ó Colmáin) ${ }^{83}$ Milo Coffyne (Coffin) gained access to the franchise by virtue of his wife Katherine Boyane in 1480. ${ }^{84}$ Coffin is an English occupational name for a basket maker, but there are no records of it being used by an Irish person, and 'Milo' was not a first name much favoured by Irishmen who took English first names, so this man was most likely of English ancestry. O'Boyhan is an Irish name common in Westmeath, but the original Gaelic form is unknown. ${ }^{85}$ These cases in which an English man gained the franchise of Dublin through his Irish wife are doubly revealing; in addition to their relevance to

\footnotetext{
77 Berry, Wills...Tregury and Walton, 65.

${ }^{78}$ As Walsh was initially used as a surname by many different, unrelated Welshmen, it does not make sense to speak of a 'Walsh' family; people of this same surname could be entirely unrelated to one another. This individual could be related to the gaelicised Walsh family of the south Dublin marches, but he could equally be part of a different Walsh lineage: Edward McLysaght, Irish families, (Dublin, 1991), 155-6; Maginn, 'English marcher lineages', 113-36.

${ }^{79}$ Lennon and Murray, Dublin city franchise roll, 57. Ó Catharnaigh is a Meath surname, and the nickname given to this family, Shynnah (An Sionnach), was also found as a surname in Dublin in this period: J.T. Gilbert, Calendar of the ancient records of Dublin, (18 vols, Dublin, 1889), vol. 1, 324, 317; MacLysaght, Surnames of Ireland, 171.

${ }^{80}$ Gerald of Wales describes these Flemish settlers in Wales in glowing terms in W. Llewelyn Williams (ed.), Itinerary through Wales: and a description of Wales (London, 1908), 77.

${ }^{81}$ McLysaght, Irish families, 88. The Fleming family was found throughout the four counties but the head of the family was the baron of Slane, Co. Meath: Kennedy Abraham, 'Upward mobility in later medieval Meath', History Ireland 5 (4) (1997), 15-20: 16.

${ }^{82}$ Gilbert, Ancient records Dublin, vol. 1, 334. The Dublin Nangles generally used the form 'Nangle' for their name, while the Kildare Nangles often used a gaelicised version MacCostello (Mac Oisdealbhaigh) and sometimes appear as 'Nangle alias MacCostello'. Orpen suggested that MacCostello was 'Mac Jocelyn' from the founder of the line, Jocelyn de Nangle, who came to Ireland with Hugh de Lacy, and others have followed him in this argument: Bliss, Tremlow, et al., Calendar papal registers, vol. 8, 112; Duffy, 'The problem of degeneracy', 95; G.H. Orpen, Ireland under the Normans (4 vols, Oxford, 1920), vol. 3, 35; MacLysaght, Irish families, 63.

${ }^{83}$ Lennon and Murray, Dublin city franchise roll, 10. Ó Colmáin is a common Irish name, while the spelling Coleman, with an -e. is often Scottish; in this context it is almost certainly an Irish name: MacLysaght, Surnames of Ireland, 51. Southern is an English descriptive surname, frequently found in Meath from the fourteenth century on, while Daynell may possibly be a form of the English surname Dayrell. The sound of the surname Daynell suggests an English origin, and a member of the family, John Daynell, was sent to England from Ireland in the 1490s to meet with the English king, and this furthers the impression that this was a settler family rather than an Irish one: MacLysaght, Surnames of Ireland, 276; Mark Antony Lower, A dictionary of surnames (London, 1988) (facsimile of J.R. Smith, 1860 edn), 84; J. Gairdner, Letters and papers illustrative of reigns of Richard III and Henry VII (2 vols, London, 1863), vol. 2, appendix B, 310-11. Mulghan may be Ó Maolagáin, a Donegal name, or Ó Maolachain, the name of an east Ulster family. The sound of it is very Irish, and it is very likely that it is an anglicised form of some Irish name. The name is common in both Louth and Dublin. The Ulster provenance of each of the name above fits well with the pattern of migration from Ulster to the four counties region: Booker, 'Gaelicisation and identity', 48, 73, 112; MacLysaght, Surnames of Ireland, 206, 226-7.

${ }^{84}$ Lennon and Murray, Dublin city franchise roll, 15.

85 This could also be Ó Baoighealláin, an Irish name from Louth and Meath: MacLysaght, Irish families, 44.
} 
the current discussion, they also show that it was not unusual for Irish women to be granted the citizenship of Dublin. ${ }^{86}$ These women may have been granted the franchise of the city because of their own trade or craft. The franchise roll records that Cecelia Colman was admitted to the city after serving her apprenticeship in 1473, two years before her marriage to Richard Daynell, and many other women were admitted after being apprentices or because of a particular skill. ${ }^{87}$ They may also have become citizens by virtue of being the daughters or widows of franchise holders, and then in turn passed this citizenship to their new husbands. The records of the Waterford town council reveal that in that town, Irishmen frequently married widows and daughters of freemen to secure their own citizenship. ${ }^{88}$ The Waterford town council considered this such a problem that they enacted ordinances against it; although it is clear that inter-ethnic marriage also occurred among the townspeople of Dublin and that citizenship of the city could be transferred via marriage, no such ordinances survive from Dublin.

Near the close of the century, in 1495, John Cougane (Ó Cuagáin), a carpenter, became a citizen as he was married to Joneta Locum, a freewoman, who bore a non-Irish but unidentified surname. ${ }^{89}$ Finally, Joneta O’Neill (Ó Néill), wife of Thomas Bron, or Brown, a Dublin notary, was the executrix of Brown's will in $1496 .{ }^{90}$ Joneta seems to have been somewhat anglicised, as, like many Irish inhabitants of the four counties, she did not always use the ' $\mathrm{O}$ ' in her surname, and it was written as both 'Neill' and 'O'Neill'. She may have been a member of the Neill family of Clondalkin who were well-established in Dublin by the mid-fourteenth century when Simon Neill pleaded for his right to English law as a member of Uí Néill, one of the 'five bloods' allegedly granted that privilege by Henry III in 1218-19. ${ }^{91}$

One particular Irish family, the Kellys, appears very regularly in the records of fifteenthcentury Dublin. John Ingerame (Ingram) became a Dublin citizen in 1476, by virtue of his wife Anne Kele’s (Ó Ceallaigh) citizenship. ${ }^{92}$ Another Kelly, a mariner named Walter, was married to Margery Dennyse (Dennis) in 1478 and thus gained entry to the franchise. ${ }^{93}$ In 1500, Henry Kenwyke (Kenwick) was made a citizen of Dublin, 'in right of wife', as he was married to Isabel Kelly. ${ }^{94}$ We can add to these the marriage of William Kelly and Anna Whetall (Whitehall), whose deaths are recorded in the late fifteenth-century or early sixteenth-century book of obits of Christ Church cathedral. ${ }^{95}$ In 1487, Thomas Kelly was described as the son and heir of Alison Newbery, daughter of Thomas Newbery, who was a mayor of Dublin, and his wife Dame Margaret Nugent. ${ }^{96}$ The will of John Staunton, who was enfeoffed with some of Thomas Newbery's land, stipulated that Kelly

${ }^{86}$ For more on Irish citizens of Dublin see Sparky Booker, 'An English city? Gaelicization and cultural exchange in late medieval Dublin’ in Seán Duffy (ed.), Medieval Dublin X (Dublin, 2010), 287-98.

${ }^{87}$ Gilbert, Ancient records Dublin, vol. 1, 349. For more women citizens see Gilbert, Ancient records Dublin, vol. 1, 330-69; Lennon and Murray, Dublin city franchise roll, passim.

88 Tenth Report of Historical Manuscripts Commission, appendix V (London, 1885), 303, 307.

${ }^{89}$ Lennon and Murray, Dublin city franchise roll, 31.

${ }^{90}$ Lennon and Murrary, Dublin city franchise roll, 69.

91 Otway-Ruthven, 'The native Irish and English law', 6; Berry, Wills...Tregury and Walton, 94-9, 220; Francis Elrington Ball, A history of the County Dublin (5 vols, Dublin, 1906), vol. 4, 111. The original plea roll for this case has been destroyed but a copy has been preserved in Brewer and Bullen, Cal. Carew MSS, vol. 5, 452; and Sir John Davies discusses this case in John Barry (ed.), 'A discovery of the true causes why Ireland was never entirely subdued (1612)' (Dublin, 1969), 103. For the notion of the 'five bloods': Otway-Ruthven, 'The native Irish and English law', 6; Frame, 'Les Engleys nées en Irlande', 88, note 20.

${ }^{92}$ Lennon and Murray, Dublin city franchise roll, 11. The name Ingram arrived in England with the Normans; it may be derived from the personal name Ingelramus: Lower, A dictionary of surnames, 168.

${ }^{93}$ Lennon and Murray, Dublin city franchise roll, 12.

${ }^{94}$ Lennon and Murray, Dublin city franchise roll, 36. This 'Kenwyke' is most likely from the Welsh 'Cynwrig' because MacKendrick, the Gaelic form, probably would retain the Mac prefix in some form, not drop it entirely: Reaney and Wilson, Dictionary of English surnames, 263.

95 J.C. Crosthwaite, The Book of obits and martyrology of the cathedral church of the Holy Trinity, commonly called Christ Church, Dublin (Dublin, 1844), 51. Whitehall is an uncommon English name, which was found in England by the fourteenth century: Reaney and Wilson, Dictionary of English surnames, 487.

96 Alison was thus of wealthy, established English stock on both her maternal and paternal sides: Mary Ann Lyons, 'Lay female piety and church patronage in late medieval Ireland' in Brendan Bradshaw and Daire Keogh (eds), Christianity in Ireland: revisiting the story (Dublin, 2002), 57-75: 68. 
receive two messuages in Skinner's Row, inside the city walls. ${ }^{97}$ It would appear then that Alison Newbery, daughter of the mayor, must have married an Irishman by the name of Kelly, and had a son by him.

This Dublin-based Kelly family was, one imagines, significantly anglicised, as many of its members were citizens and married into settler families. ${ }^{98}$ Their name bears the evidence of this anglicising process, as it was rarely written with the original ' $\mathrm{O}$ ' prefix. They were also, it seems, sufficiently wealthy and socially accepted to marry into the family of a mayor of Dublin. They can be found more often in fifteenth-century Dublin city records than any other family of Irish provenance and often as citizens and well-integrated members of the civic community. It is conceivable that this family was so English in appearance and custom that their Irish roots were not known, either to themselves or to others. ${ }^{99}$ However, given the deep-seated awareness of ancestry and descent within the colony, this is only a possibility. It is more likely that the ethnicity of these Kellys was known, particularly as their name was a widespread and well-known Irish one, and that one of their ancestors had purchased English law enabling them to participate more fully in colonial life. Their Irish descent did not, apparently, prove an insurmountable impediment in social interaction and acceptance.

\section{Intermarriage in the towns of Louth}

Like Dublin, many of the towns of medieval County Louth were home to mixed couples. In the register of John Swayne, the archbishop of Armagh (1418-1439), we learn of an inter-ethnic marriage in Dundalk which unfortunately may have come to a violent end. In 1428 there was, it seems, a rumour that Roger Michyn (Ó Miadhacháin?) of Dundalk had beaten his wife, Joanna Walsh, to death. ${ }^{100}$ Swayne, presumably convinced of Michyn's innocence in the matter, ordered the people of the diocese to stop defaming him. Another somewhat violent case involving intermarriage comes from the town of Termonfeckin, Co. Louth, where Catherine Mckesky (MacAscaidh) was married to John Cusake, of the long-established Meath and Kildare based Cusack family, who first came to Ireland in the early thirteenth century with King John. ${ }^{101}$ The marriage was annulled in 1438 because Catherine had not consented willingly to the match, and was severely beaten by her parents in their efforts to force her acceptance of it. ${ }^{102}$ These violent marriage cases and divorces may give the impression that these inter-ethnic marriages were particularly prone to such troubles, but as they are taken from records of the archbishop's court which dealt with divorces and marital problems, they do not give a balanced view of such unions. Presumably many mixed marriages in County Louth were successful and thus we have no record of them, as there was no reason for them to appear in the archbishops' registers.

A rather complicated matrimonial case from Termonfeckin in 1487 determined that the marriage of Joan Norreys to William Elise was valid, as, although Joan had a pre-contract with a man named Robert Sowleghan, it was invalidated by Robert's previous marriage to 'Fynwole ny

\footnotetext{
${ }^{97}$ Lennon and Murray, Dublin city franchise rolls, 60.

98 Ó Ceallaigh was a very widespread surname, but this Kelly family may have been related to the Uí Cheallaigh of North Wicklow: MacLysaght, Irish families, 112; Linzi Simpson, 'Anglo-Norman settlement in Uí Briúin Chualann', in Ken Hannigan and William Nolan (eds), Wicklow: history and society (Dublin, 1994), 191-236: 202, 224-5.

99 They had been in Dublin for many years, and in the 1280s, Kellys appeared frequently in the Dublin area. The placename Ballynakally in County Dublin also suggests a long-standing family of that name: H.S. Sweetman (ed.), Calendar of documents relating to Ireland (5 vols, London, 1879), vol. 3, 60, 83, 150, vol. 4, 42.

100 Chart, Register of John Swayne, 95. Michyn, according to Edward MacLysaght, is O’Meehan, or 'Ó Miadhagain', a Monaghan family, but in this instance, it is more likely to be O’Meegan, or 'Ó Miadhacháin', a family still found in the Dundalk area. In the middle of the fifteenth century the vicarage of Clonkeen, northwest of Ardee, was held by William Omychan and the name, sometimes written with the 'O' prefix that confirms its Irish origin, is regularly found in Louth in the fifteenth century: MacLysaght, Surnames of Ireland, 127; TCD MS 557, Register Prene, vol. 5, 325.

${ }^{101}$ Hubert Gallwey, 'The Cusack family of Cos Meath and Dublin', IG 5 (3) (1976), 298-313, IG 5 (4) (1977), 464-470; IG 5 (5) (1978), 591-600; IG 5 (6) (1979), 673-687; IG 6 (2) (1981), 130-153, IG 6 (3) (1982), 285298.

${ }^{102}$ Chart, The register of John Swayne, 165.
} 
McMahon’ (Finnuala Iníon Mhac Mathghamhna). ${ }^{103}$ This case is somewhat unclear, as while Norreys and Elise are English and 'ny McMahon' is Irish, Sowleghan may represent the Irish Ó Súileacháin or, more improbably, the English name 'Solingham' ${ }^{104}$ While there is an intermarriage in this tangled case, it is difficult to say whether it occurred between Joan Norreys and Robert Sowleghan (if Robert was Irish) or between Robert and Fynwole ny McMahon (if he was English). On balance, considering the rarity of the name 'Solingham', it is more probable that it was Joan and Robert whose contract was inter-ethnic. Termonfeckin was later home to an Irish man named Seth O’Galy (Ó Ceallaigh?), husband of the English Joan Symcock. In 1498 O'Galy testified about the goods of his wife's previous husband, the deceased John Thonder. ${ }^{105}$

Drogheda, the largest town of County Louth, was the site of the marriage of Shaglyn Carnele and Joanna Rochford in $1460 .{ }^{106}$ Unlike many Irish people who intermarried with the English, Carnele (Ó Catharnaigh?) used an Irish first name, [Maol ] Seachlainn, rather than an English one; Rochford was a surname used by a very widespread settler family in Ireland. ${ }^{107}$ Drogheda was also the home of the bigamous Irishman Edmund Cahule (Ó Cathail) in 1488. In the course of Cahule's divorce from his Irish wife, Agnes Skegan (Mac Sceacháin), the archbishop's court discussed his preexisting marriage to a woman named Joneta Coste. ${ }^{108}$ This may be the English surname Coste, a shortened form of the name Constantine or, perhaps, de Costentin. ${ }^{109}$ In the same year, the deliberations of the archbishop's court revealed another mixed relationship, albeit not a marriage. The Irish woman Matilda ny Mcmaghawun (Iníon Mhac Mhathghamhna) had 'carnal knowledge' of Henry Verdon, who was probably a member of the de Verdon family of County Louth. ${ }^{110}$ This sexual relationship invalidated Matilda’s subsequent marriage to Patrick McKenan (Mac Fhionnáin). ${ }^{111}$

Ardee, Co. Louth, was the location of the matrimonial troubles which arose in 1452 'between Jenkyn Alton and Alice Ohanlowan, by reason of a pre-contract, and a divorce case between Jenkyn and Agnes Frene by reason of a post contract'. ${ }^{112}$ Alton is a toponymic English name, originally 'D'Alton'; the form most usual in Ireland was Dalton, used by the large, gaelicised Westmeath family. ${ }^{113}$ Ohanlowan is Ó hAnluain, the great south-east Ulster sept. ${ }^{114}$ In the same year (1452)

\footnotetext{
103 Sughi, Register Octavian, vol. 1, 5, vol. 2, 21. For this powerful Irish midlands family see note 132.

${ }^{104}$ MacLysaght, Irish families, 280.

105 Sughi, Register Octavian, vol. 1, 141. Thonder is a Norse name originally, while Symcock is English and O'Galy is undoubtedly Irish (although its Gaelic form is uncertain). The linking of these three people via marital connections demonstrated the levels of assimilation between the various peoples of medieval Ireland over the course of the middle ages.

${ }^{106}$ Brendan Smith (ed.), The register of Nicholas Fleming: Archbishop of Armagh 1404-1416 (Dublin, 2003), 265; Kenny, Anglo-Irish and Gaelic women, 53.

107 Carnelley is also a Norman name taken from the word for 'battlements' but given that this man lived in Louth and bore an Irish first name, an Irish provenance is vastly more likely: Reaney and Wilson, Dictionary of English surnames, 84; MacLysaght, Surnames of Ireland, 171, 259.

108 Sughi, Register Octavian, vol. 1, 89-90, vol. 2, 439. Mac Sceacháin is an Airghialla name that is sometimes anglicised as Thornton, a name still found in County Louth: MacLysaght, Surnames of Ireland, 285.

109 Reaney and Wilson, Dictionary of English surnames, 111. The de Costentin family came to Ireland in the 1170s and held lands in counties Offaly, Laois, and Westmeath. Their relations and descendants may have taken the shortened form of their surname 'Coste': M.V. Clarke, Register of the priory of the Blessed Virgin Mary at Tristernagh (Dublin, 1941), vii-xii.

110 This family's founder, Bertram de Verdon, came to Ireland in the company of John, lord of Ireland, in 1185, and the family had been sizable landowners in counties Louth and Meath from that time on. For more on their role in the community of county Louth in the fourteenth century see Brendan Smith, 'A county community in early fourteenth-century Ireland: the case of Louth', The English Historical Review 108 (1993), 561-88. For the family origins and branches in England and Wales see Mark Hagger, The fortunes of a Norman family: the de Verduns in England, Ireland and Wales, 1066-1316 (Dublin, 2001).

${ }^{111}$ Sughi, Register Octavian, vol. 2, 23. Kennan was one of the most common names found in Ardee in the 1659 census, and perhaps these people lived in that area of Louth: MacLysaght, Surnames of Ireland, 176.

${ }^{112}$ Quigley and Roberts, Registrum Mey, 266-7.

113 Nicholls, Gaelic and gaelicized Ireland, 209-10.

${ }^{114}$ Katharine Simms, 'Medieval Armagh: the kingdom of Oirthir (Orior) and its rulers the Uí Annluain (O’Hanlons)' in A.J. Hughes and W. Nolan (eds), Armagh history and society (Dublin, 2001), 187-216;
} 
Isabella Conlan of Ardee claimed that John Tallon had agreed to marry her and not done so, but as she was unable to prove her case in the archbishop's court, John was not held responsible. ${ }^{115}$ Conlan is the anglicised form of several common Irish surnames, but in Leinster it is most usually Ó Caoindealbháin, while Tallon is the name of an English Leinster family who gave their name to Tallonstown in Louth. ${ }^{116}$ The remarriage of a mixed couple, Joan Knock and Hugo Myghyn (Ó Miadhacháin?), in 1492 also took place in Ardee. ${ }^{117}$ In 1487 Matilda Messynge of Carlingford, another mid-sized town of County Louth, was described as the widow of John Glasse Omorghy, an Irishman. ${ }^{118}$ John's nickname 'Glas' was a descriptive one, meaning 'grey-haired', while his surname's Irish form was 'Ó Murchadha'. ${ }^{119}$ It is notable that John used a typical Irish descriptive nickname, suggesting that he may have remained in an Irish-speaking milieu, despite being married to an English woman and living in County Louth. ${ }^{120}$

\section{Mixed marriages in rural areas}

There are fewer extant examples of mixed marriages in rural areas of counties Meath, Dublin, Kildare and Louth, but as the records are more numerous and informative about urban areas in general, especially Dublin city, this does not necessarily indicate that such marriages were actually more common in towns and cities. Similarly, the known number of inter-ethnic marriages in each county reflects the survival of sources. Louth, with its plentiful records kept by the archbishops of Armagh and the family records known as the Dowdall deeds, which are very informative about marriage, and Dublin, with its variety of relevant ecclesiastical and secular sources, provide the greatest number of mixed marriages. Kildare and Meath have less numerous records, and fewer known mixed marriages (or indeed marriages of any kind). The two are surely related, and one would hesitate to ascribe this difference to any significant disparity in the attitude of the English communities of these counties, or the attitude of urban as opposed to country-dwellers. There are, moreover, a handful of possible rural examples.

In the Dublin hinterlands one of the ubiquitous Dublin Kelly family married an English woman. The 1471 inventory of Thomas Kelly of Skidoo, a townland in Swords, Co. Dublin, records his wife's name as Margaret Lex, an English name from the Latin for 'law'. ${ }^{121}$ In 1436 an inquisition was held on the goods of Manus Colgyn (Maghnus O/MacColgan) and Joneta Welouke, who lived in the parish of Collon, a few miles north of Drogheda. The inquisition implies that their possessions were held in common, and thus that they were probably married. They did however, have separate

Katharine Simms, 'The O'Hanlons, the O'Neills and the Anglo-Normans in thirteenth-century Armagh', Seanchas Ardmhacha 9 (1) (1978), 70-94.

${ }^{115}$ Quigley and Roberts, Registrum Mey, 198.

116 MacLysaght, Surnames of Ireland, 45-6, 282. The Uí Caoindealbháin were the ruling family of Trim, Co. Meath in the eleventh century and Isabella was probably a descendant of these Irish petty kings: Michael Potterton, Medieval Trim: history and archaeology (Dublin, 2005), 57-8.

${ }^{117}$ This could refer to Knock in County Louth, but Knock is also a Scottish name, later seen more commonly in the form 'Knox'. If it is an Irish toponym rather than a form of 'Knox', it is possible that Joan Knock was Irish rather than Scottish, but the use of toponyms was more common among the English of Ireland than the Irish. See note 100 for Myghyn.

${ }^{118}$ McNeill and Otway-Ruthven, Dowdall deeds, 208.

${ }^{119}$ Ó Murchadha, the Irish form of the modern name Murphy, is one of the more widespread Irish surnames but as he lived in northern Louth, John glas was probably a member of an Ulster Ó Murchadha lineage: MacLysaght, Irish families, 132-3.

120 The question of what language was spoken in the towns of Louth is an interesting one. It has been argued that English was the dominant vernacular in the towns, and this is attested by slander cases from the courts of the archbishops of Armagh. However, it is likely that many inhabitants of the towns were bilingual and could speak both English and some level of Irish by the fifteenth century, and there is onomastic evidence for this from the fifteenth century: Ellis, 'Nationalist historiography', 11; Steven Ellis, 'Crown, community and government in the English territories, 1450-1575' in History 71 (1986), 187-204; Quigley and Roberts, Registrum Mey, 53, 73-4, 93, 142; Sughi, Register Octavian, 124; Booker, 'Gaelicisation and identity', 184225.

${ }^{121}$ Berry, Wills...Tregury and Walton, 18. 
executors, which confuses the picture somewhat. ${ }^{122}$ In 1442 Johanna Ohoire of Drumcath, Co. Louth succeeded in having her marriage to William Pembroke declared invalid on the grounds that she was coerced. ${ }^{123}$ Pembroke's name is a Welsh toponymic, but though Ohoire is Irish, its Gaelic form is uncertain; it may be the Armagh name 'Ó hÉir', as Irish people from families in Armagh and other areas of Ulster were often resident in Louth up until the fifteenth century. ${ }^{124}$ Sometime in the 1440s the Irish woman Sabina Necarvell (Sadhbh Iníon Uí Chearbhaill) was the wife of Nicholas Kenver of the parish of Kilsaran, a townland in County Louth. ${ }^{125}$ It is likely this couple was a rural rather than urban one, as they were identified with reference to a townland and parish rather than a town.

In 1445, again in Kilsraran, Agnes Mckynkerde (Mac an Airchinnigh?) sought a divorce from John Olounchegan (O Luchráin/Ó Longargáin?) on the grounds that he had been previously married to Jenet Petendy. ${ }^{126}$ The name Petendy is a form of de Repenteny, the surname of an English family who settled in County Louth in the late twelfth century. ${ }^{127}$ In 1449, the registers of the archbishop of Armagh again record a mixed couple-William Pumrell and Marian neu Odonnony-but they do not say where the couple lived. It is almost certain that they were from somewhere in Louth, and as people from towns were usually identified as 'of Drogheda', 'of Ardee', etc., it may be that they lived in a rural area of the county. ${ }^{128}$ Pumrell sought a divorce from his wife, de facto Marian neu Odonnony (Muireann (?) Iníon Uí Donnghaile?); Pumrell was not a common surname in either medieval England or Ireland, but the sound of the name is English, and Irish surnames almost never begin with 'p', so it is probably an English surname. William's wife Marian used a form of the County Tyrone surname Iníon Uí Donnghaile that was largely unanglicised, suggesting that she had not entirely assimilated into English culture, despite her marriage to an Englishman, and her (likely) residence somewhere in Louth. ${ }^{129}$

In 1450 another County Louth couple, Joanna Nangle and William Gernon, were engaged in a dispute about their marriage. ${ }^{130}$ Both Nangle and Gernon came from long-established English gentry families, based in Meath/Kildare and Louth respectively. ${ }^{131}$ The major issue in their dispute was, however, the previous marriage of William to 'Onnem Mcmaguna' (Úna or Iníon(?) Mac Mathghamhna) who was probably a member the MacMahon family, the ruling Irish dynasty of Airghialla in northern County Monaghan. ${ }^{132}$ John Haddesors of Cappogue (near Dunleer, Co. Louth) also married into this prominent Irish family. In 1467 he was accused by the Irish parliament of committing arson, murder and robbery in Meath and Louth, and the parliament also records, as part

${ }^{122}$ Chart, Register of John Swayne, 166. O or MacColgan is likely that of an Ulster family of Derry/Tyrone: MacLysaght, Surnames of Ireland, 50.

${ }^{123}$ TCD MS 557, Register Prene, vol. 5, 144-9; Art Cosgrove, 'The Armagh Register: An underexplored source for late medieval Ireland', Peritia 6-7, (1987-8), 312.

${ }^{124}$ MacLysaght, Surnames of Ireland, 146, 243. As discussed in note 18, the descendants of Welsh people, like the Welshes previously mentioned and perhaps this Pembroke, were, by the fifteenth century and in the intensely dichotomous world view of the English of Ireland, considered part of the English community of Ireland.

125 TCD MS 557, Register Prene, vol. 5, 82. Kilsaran is about half-way between Drogheda and Dundalk, along the eastern coast of Louth.

126 TCD MS 557, Register Prene, vol. 5, 138. Mckynkerde may be this name, 'Mac an Airchinnigh', meaning ‘son of the erenagh': MacLysaght, Surnames of Ireland, 166.

${ }^{127}$ According to Brendan Smith, this family practised intermarriage in the fourteenth century: Colonisation and conquest, 125.

${ }^{128}$ The vast majority of marital cases that came before the archbishop's court were from County Louth, and almost all mixed marriages in the registers come from that county. A William Pomrell was a vicar of St Peter's Drogheda in 1559, further supporting the idea that this was a Louth family: Reverend J.B. Leslie, Armagh clergy and parishes (Dundalk, 1911), 237.

${ }^{129}$ Quigley and Roberts, Registrum Mey, 143.

130 TCD MSS 557, Register Prene, vol. 5, 224.

${ }^{131}$ For the Nangles of Meath, see C.C. Ellison, 'Some aspects of Navan history', Riocht Na Midhe 3 (1) (1963), 33-56. See note 84. The Gernon family had been in Ireland since the initial settlement, as they came to Ireland in the company of Hugh de Lacy: Smith, Colonisation and conquest, 48.

132 Katharine Simms, 'The MacMahon pedigree: a medieval forgery' in David Edwards (ed.), Regions and rulers in Ireland, 1100-1650 (Dublin, 2004), 27-36; Philip Moore, 'The MacMahons of Monaghan (15001593)', Clogher Record: Journal of the Clogher Historical Society 1 (3) (1955), 22-38. 
and parcel of his villainy, that he married the daughter of McMahon, 'the King's Irish enemy'. ${ }^{133}$ Haddesors had a history of conflict with the Dublin government-he had been attainted of treason in 1447, and nine years later was included in a list of men from Louth called to Dublin Castle to account for various crimes. His attainder was retracted in 1458 although he was warned that he must be 'of good rule and conduct' in the future and use 'English dress', which suggests that even before he married MacMahon's daughter he had adopted Irish apparel. ${ }^{134}$

Several members of a branch of the Desmond Geraldines who lived in Allen, Co. Kildare, entered into marriages with Irish women in the fifteenth century. Sometime in the middle of the century Philip FitzMorish [FitzGerald] married an Irish woman named Elizabeth O Dunne (Ó Duinn) of Iregan, whose family was centered in Laois and may have been neighbours of these FitzGeralds. ${ }^{135}$ The FitzGeralds of Allen were a fairly weathly and gaelicised branch of the Geraldines, and frequently bore Irish names and nicknames as well as using Irish methods of succession. ${ }^{136}$ Richard FitzMorice William [FitzGerald] of Allen had a daughter who married Hugh O Coffey (Ó Cobhthaigh) of Carn, (modern County Westmeath) in the second half of the fifteenth century, and his son, Maurice FitzRichard [FitzGerald], had an Irish concubine, 'Marger ny Beghan' (Ó Beacháin) by whom he had a son. ${ }^{137}$

An example of intermarriage from the diocese of Meath comes from the papal registers in 1413, which contain a dispensation allowing Anne Palmer and John Malghan of Meath to marry, although they were related in the prohibited degrees. ${ }^{138}$ Their place of residence within Meath was not stated, although the anglicised surname used by Malghan and the English first names used by both suggests that they may have lived in the more English east of the diocese, rather than in the west (modern County Westmeath). A similar dispensation was granted to 'William Fitsgerrod (Fitzgerald) and Mor inge Ycon[co]beir (Mór Iníon Uí Chonchobhair)' of Kildare in 1424, as William had sexual relations with a kinswoman of Mór, and was thus, in the eyes of the church, too closely related to her to marry without dispensation. ${ }^{139}$ These examples, in which members of the settler community are shown to have been 'within the prohibited degrees' of relation to Irish people, demonstrate how closely linked the peoples of medieval Ireland were, and that these mixed marriages were not isolated events, but rather part of a much larger trend of interaction between the two peoples expressed, in this case, through marital and sexual relationships.

\footnotetext{
133 Berry and Morrissey, Statute rolls...Edward IV, vol. 1, 611. This may have been the daughter of Réamonn Mac Mathghamhna, who was head of the family from 1467 to 1484 . The Haddesors or de Hadsors were a Louth family, and involved in local government: Milo de Haddesors had been sheriff of Louth in 1383 and 1392, while an earlier John Haddesors of Cappoge was a keeper of the peace for Louth in 1373, as was a Reginald Haddesors in 1385 and 1400: McNeill and Otway-Ruthven, Dowdall deeds, 115, 130; Robin Frame, 'Commissions of the peace in Ireland, 1302-1461', Analecta Hibernica 35 (1992), 1, 3-43: 21-2.

${ }^{134}$ Berry, Statute rolls...Henry VI, 93, 441, 533, 755.

${ }^{135}$ K.W. Nicholls, 'Geraldines of Allen', IG 4 (1) (1968), 93-108: 98. Allen is in county Kildare, just north of Kildare town.

${ }^{136}$ Nicholls, 'Geraldines of Allen'; Mary Anne Lyons, Church and society in County Kildare, c. 1470-1547 (Dublin, 2000), 51. Many of these Geraldines appear with Irish nicknames on the earl of Kildare's 1513-30 lists of those to whom he gave horses: J.T. Gilbert, 'Manuscripts of his Grace, Duke of Leinster' in Appendix to the ninth report of the royal commission on historical manuscripts (London, 1883), 279-86, reprinted in Gearóid Mac Niocall, Crown survey of lands 1540-41 with the Kildare rental begun in 1518 (Dublin, 1994).

${ }^{137}$ Nicholls, 'Geraldines of Allen', 94-5; Lyons, Church and society, 78. Other FitzGeralds from outlying areas, particularly in Westmeath, also engaged in intermarriage. Oliver Fitzgerald of Belagh, Co. Westmeath, son of the eighth earl of Kildare married Meadhbh, daughter of Cahir O'Connor in the first few decades of the sixteenth century. His children also married into Irish families: K.W. Nicholls, 'The descendants of Oliver FitzGerald of Belagh', IG 4 (1) (1968), 2-8.

${ }^{138}$ Bliss, Tremlow et al., Calendar papal letters, vol. 4, 452. See note 83 on Mulghan.

139 Bliss, Tremlow et al., Calendar papal registers, vol. 7, 362. The rules of the church concerning incest extended to forbid marriage not only between actual blood relations, like second and third cousins, but also those linked by sexual relationships and by the ties of godparenthood: Cosgrove, 'Marriage in medieval Ireland', 27.
} 


\section{Conclusion}

The union in marriage of Irish individuals to men and women of English descent took place throughout the fifteenth century, although such marriages may have been even more prevalent in the second half of the century. These marriages occurred in high numbers in Dublin city, in the towns and rural areas of County Louth, and also in Meath and Kildare, probably with even greater frequency than the records show. Intermarriage among the elite has been the most often cited and is the most well known, but marriage spanned the social spectrum and English merchants, townspeople, gentry, and small landowners also married Irish people. The prevalence of intermarriage in the four counties, traditionally seen as the most English region of the colony, suggests a high level of interaction and accommodation in this area between the two peoples of late medieval Ireland, as well as a willingness on the part of the English to ignore parliamentary prohibitions and social pressure against intermarriage.

Many of the Irish people who lived in the four counties and intermarried with the English were anglicised to some extent, as their names show, and yet, the focus on descent demonstrated by inquisitions into ethnicity and other material from the sources indicates that they would still have been considered 'Irish' in the eyes of the colonial community. As has been noted by others, the neat dichotomy of English and Irish that characterised so much of late medieval thought from the four counties was clearly unsustainable on the ground, and the existence of many half-Irish/half-English people produced by intermarriage highlights the difficulty of defining these two groups by descent, as the colonial community increasingly attempted to do in the fifteenth century. Although parliamentary records show that there were repeated attempts to preserve the 'Englishness' of English Ireland, these intermarriages demonstrate the failure of the exercise, even at the core of the colony. By the end of the fifteenth century, society in these four counties, Kildare, Meath, Louth and Dublin, was not purely English, and nor was it Irish, but it was rather an, at times uneasy, marriage of the two. 